\title{
Morpho-physiological Modulations in Rice (Oryza sativa) by Foliar Application of Phospholipase-C Inhibitor Neomycine under Saline Conditions
}

\author{
Atifa Masood and Muhammad Shahbaz* \\ Department of Botany, University of Agriculture, Faisalabad 38040, Pakistan \\ "For correspondence: shahbazmuaf@yahoo.com
}

\begin{abstract}
The present study was conducted to assess modulation in morpho-physiological attributes of rice (Oryza sativa L.) cultivars (Bas-385, Bas-2000, Bas-370 and Shaheen) at vegetative stage by phospholipase C (PLC) inhibitor neomycine (control and $100 \mu M$ ) under salt stress (control, 50, 100 and $150 \mathrm{~m} M \mathrm{NaCl}$ ). Salt stress significantly reduced shoot fresh and dry weights, shoot length, water potential, osmotic potential, net $\mathrm{CO}_{2}$ assimilation rate $(A)$, transpiration rate $(E)$, stomatal conductance $\left(g_{s}\right)$, non-photochemical quenching $(N P Q)$, coefficient of non-photochemical quenching $\left(\mathrm{q}_{\mathrm{N}}\right)$ and photochemical quenching $\left(\mathrm{q}_{\mathrm{P}}\right)$ while increased efficiency of photosystem-II $(F v / F m)$, leaf free proline, shoot and root $\mathrm{Na}^{+}, \mathrm{K}^{+}$and $\mathrm{Ca}^{2+}$ level. Foliar application of neomycine increased shoot length, chlorophyll $b, A, E$, electron transport ratio $(E T R)$, leaf free proline and shoot $\mathrm{K}^{+}$. Neomycine remarkably reduced water potential, $F v / F m$, root $\mathrm{K}^{+}$and shoot $\mathrm{Ca}^{2+}$. Of all rice cultivars, cv. Bas-2000 performed better in growth, water relation and photosynthetic attributes under saline and non-saline conditions. () 2016 Friends Science Publishers
\end{abstract}

Keywords: Salinity; Phospholipase C; Neomycine; Rice; Growth attributes; Photosynthesis

\section{Introduction}

Various environmental factors adversely affect plant growth and yield of crops ( $\mathrm{Li}$ et al., 2011). Of these factors, drought, salt and temperature stress are limiting ones for the growth and productivity (Liu et al., 2011). Salinity is a big threat for crop production all over the world (Kchaou et al., 2010). Being an agricultural country, economy of Pakistan mainly depends on agriculture (Ahmad et al., 2013) and salinity induced losses in agricultural sector are very high (Jouyban, 2012). Salt stress causes reduced crop growth due to a variety of processes like osmotic stress, ion toxicity, ionic imbalance and oxidative stress (Shahbaz et al., 2013; Shahbaz and Ashraf, 2013). Growth and yield losses are due to high accumulation of sodium as well as chloride ions under saline environment (Shafi et al., 2010). Salinization leads to reduced plant growth, chlorophyll contents (Nivas et al., 2011) efficiency of Photosystem II (Saleem et al., 2011) and gas exchange characteristics (Shafi et al., 2011). Primarily salinization causes water deficit effects (Kausar $e t$ al., 2013) that disturb water relations of crop plants (Shafi et al., 2010). Homeostasis in water relations changes under salt stress condition and leads to the accumulation of ions at both cellular as well as whole plant level and reduces plant growth (Hossain et al., 2011).

Due to biotic and abiotic stresses, a series of intracellular signals of phospholipase C (PLC) are produced, which acts as precursor of inositol triphosophate $\left(\mathrm{IP}_{3}\right)$ and diacylglycerol (DAG) (Holdaway-Clarke and Hepler, 2003). These signals cause the expression of responses such as growth inhibition or cell death (Mahajan et al., 2008). PLC acts as an enzyme and helps in cell regulation, lipid metabolism (Wang, 2001) as well as release of calcium. Low concentration of PLC reduces the activity of stoma due to abscisic acid (Hunt et al., 2003). Of two classes of PLCs, Phosphoinositide-specific phospholipase C (PIPLC) plays a role in guard cell signaling, pathogenic response and carbon fixation in $\mathrm{C}_{4}$ plants (Coursol et al., 2000). PI-PLC causes lipid hydrolysis in membranes, phosphatidylinositol-4, 5-bisphosphate to produce $\mathrm{IP}_{3}$ and DAG that increases the level of cytosolic calcium (Holdaway-Clarke and Hepler, 2003). However, a PLC inhibitor reduces ABA level and cytosolic $\mathrm{Ca}^{2+}$ that results in stomatal closure (Mills et al., 2004). Under abiotic stresses plants accumulate higher level of proline by regulating proline metabolism due to PLC that was evaluated by the application of PI-PLC inhibitors. Inhibition of PLC activity by the use of U-73122 quantified by evaluating the decreased level of $\mathrm{IP}_{3}$ (Parre et al., 2007). In addition to U-73122, neomycine has also been reported as an inhibitor of PLC (Hunt et al., 2003). Neomycin inhibits the increase in guard cells $\mathrm{Ca}^{2+}$ level and causes closing of stomata (Meijer and Munnik, 2003).

To cite this paper: Masood, A. and M. Shahbaz, 2016. Morpho-physiological modulations in rice (Oryza sativa) by foliar application of phospholipase-C inhibitor neomycine under saline conditions. Int. J. Agric. Biol., 18: 710-718 
Of cereal crops, rice (Oryza sativa L.) is considered as an important staple food for most of the world's population (Joseph and Mohanan, 2013). Rice is sensitive to salt stress (Kapoor, 2011). It is more commonly grown in any country of Asia where half of the total arable land is under rice cultivation (Jamil et al., 2012). It has been reported that rice is a salt sensitive crop with optimum salinity of $3-4 \mathrm{dS} \mathrm{m}^{-1}$ (Rao et al., 2013), however it is moderately tolerant to sodicity (Gopikannan and Ganesh, 2013).

PLC is a signaling molecule as it plays a key role in plant growth and regulation however, evidence about the role of PLC in rice under saline condition is scarce in literature. We hypothesized that exogenously applied PLCinhibitor (Neomycine) may help to understand the role of PLC in physio-biochemical analysis and mechanism of salt tolerance in rice.

\section{Materials and Methods}

An experiment was carried out in net house of Old Botanical Garden, University of Agriculture Faisalabad to study the mechanism of salt tolerance of rice (Oryza sativa L.) by exogenous application of PLC inhibitor: Neomycine. Seeds of four rice (Bas-385, Bas-2000, Bas-370 and Shaheen) cultivars were obtained from Rice Research Institute, Kala Shah Kako, Lahore and were sown in soil filled pots. Transplantation was done after thirty days of germination. Four salinity (control, 50, 100 and $150 \mathrm{mM}$ $\mathrm{NaCl}$ ) levels were maintained after 21 days of transplantation. After 24 days of transplantation, two levels of neomycine (control i.e., 0 and $100 \mu M$ ) were applied as foliar spray. The experimentation was laid down in a completely randomized design with four replications. Data for various attributes were determined from the samples after three weeks of treatment application.

\section{Growth Attributes}

From each replication two plants were up-rooted carefully, rinsed with distilled water and measured the shoot length. After harvesting, shoot fresh weight of each plant was recorded with electrical balance. The dry weights were recorded after drying them in an oven at $65^{\circ} \mathrm{C}$ up to their constant weight.

\section{Photosynthetic Pigments}

Following the Arnon (1949) method the chlorophyll pigments $(a$ and $b$ ) were determined. Fresh leaf tissue $(0.25$ g) was crushed and placed in $5 \mathrm{~mL} 80 \%$ acetone solution overnight and then after centrifugation measured the optimal density at 663 and $645 \mathrm{~nm}$ with the help of spectrophotometer (IRMECO U2020).

\section{Water Relation Attributes}

Third youngest leaf from top was excised to measure water potential $\left(\Psi_{\mathrm{w}}\right)$ at 6:30 am to 7:30 am with the help of Scholander type pressure chamber (Arimad-2-Japan) by using the method of Scholander et al. (1964). Then the same leaf as used for $\Psi_{\mathrm{w}}$, stored below $-20^{\circ} \mathrm{C}$. Sap was extracted and used for the measuring osmotic potential $\left(\Psi_{\mathrm{s}}\right)$ in a vapor pressure osmometer (Vapro, 5520). Then leaf turgor potential $\left(\Psi_{\mathrm{p}}\right)$ was calculated as the difference between $\Psi_{\mathrm{s}}$ and $\Psi_{\mathrm{w}}$ values according to Nobel (1991).

\section{Chlorophyll Fluorescence}

For this purpose leaves were kept in dark by using dark adapted clips (half an hour)and then recorded chlorophyll fluorescence attributes with the help of chlorophyll fluorometer (Model, OS5P Opti Sciences, Inc. Winn Avenue Hudson, USA) following the method of Strasser et al. (1995).

\section{Gas Exchange Attributes}

Following Shahbaz et al. (2011) gas exchange characteristics were recorded from 10 a.m. to 2.00 p.m by using infrared gas analyzer (Analytical Development Company, Hoddesdon, England).

\section{Sodium $\left(\mathrm{Na}^{+}\right)$, Potassium $\left(\mathrm{K}^{+}\right)$and Calcium $\left(\mathrm{Ca}^{2+}\right)$ Determination}

Following the Allen et al. (1986) method the shoot and root (each $0.1 \mathrm{~g}$ ) were crushed and placed digestion flasks containing $2 \mathrm{~mL}$ sulphuric acid for $24 \mathrm{~h}$. The material was heated until the loss of fumes at $250^{\circ} \mathrm{C}$. One $\mathrm{mL}$ hydrogen peroxide was poured after cooling to decolorize the material. The extract was diluted up to $50 \mathrm{~mL}$ by using distilled water. Impurities were removed by filtration. Then $\mathrm{Na}^{+}, \mathrm{K}^{+}$and $\mathrm{Ca}^{2+}$ ions were determined by flame photometer (Jenway, PFP-7, UK).

\section{Free Proline Determination}

Fresh leaf tissue $(0.5 \mathrm{~g})$ was extracted in $10 \mathrm{~mL}$ sulfosalicylic acid (3\%) and then filtered using a Whatman paper. In $2 \mathrm{~mL}$ of extract, $2 \mathrm{~mL}$ acid ninhydrin and $2 \mathrm{~mL}$ glacial acetic acid were added before incubation at $100^{\circ} \mathrm{C}(60 \mathrm{~min})$. After cooling, $4 \mathrm{~mL}$ toluene was added, vortexed and measured the optimum density at $520 \mathrm{~nm}$ using a spectrophotometer (IRMECO U2020) following Bates et al. (1973) method.

\section{Experimental Design and Statistical Analysis}

Analysis of variance of data for all the parameters were calculated using the Co-STAT computer software and means were compared following Snedecor and Cochran (1980) method.

\section{Results}

Imposition of various levels of salt stress (control, 50, 100 and $150 \mathrm{~m} M \mathrm{NaCl}$ ) applied through root growing medium significantly $(P \leq 0.001)$ reduced shoot fresh and dry weights of all four rice cultivars (Bas-385, Bas-2000, 
Bas-370 and Shaheen). Of varying levels of $\mathrm{NaCl}$, the maximum reduction was observed at $150 \mathrm{~m} M$ salinity. However, foliar application of neomycine showed nonsignificant effect on shoot fresh and dry weights of all rice cultivars. Among four rice cultivars, a significant $(P \leq 0.01)$ variation was observed particularly cv. Bas-2000 performed better under control and saline conditions as compared to others (Table 1, Fig. 1).

Salt stress considerably $(P \leq 0.001)$ reduced shoot length of all four rice cultivars and maximum reduction was observed at $150 \mathrm{~m} M$ salt stress. However, foliar application of neomycine prominently $(P \leq 0.001)$ enhanced the shoot length in rice cultivars. All cultivars differed significantly $(P \leq 0.001)$ and $\mathrm{cv}$. Bas-370 performed better as compared to all other cultivars (Table 1, Fig. 1).

Imposition of salt stress did not affect chlorophyll contents. Foliar applied neomycine was also proved to be non-significant for chlorophyll $a$ and $a / b$ ratio but slightly enhanced $(P \leq 0.05)$ chlorophyll $b$. However, all four cultivars of rice showed slightly significant $(P \leq 0.05)$ variation with respect to chlorophyll $a$ and $b$ contents as cv. Shaheen and Bas-370 had higher values as compared to others under saline conditions (Table 1, Fig. 1 and 2).

Application of saline stress considerably $(P \leq 0.001)$ reduced the $\Psi_{\mathrm{w}}$ and $\Psi_{\mathrm{s}}$ of rice. Foliar application of neomycine also caused a remarkable $(P \leq 0.001)$ reduction in $\Psi_{\mathrm{w}}$ of all four rice cultivars. Effects of salt stress as well as neomycine were inconsistent for $\Psi_{\mathrm{p}}$ in all four rice cultivars. A prominent variation was observed in four rice cultivars as cv. Bas-2000 was high in water relation attributes as compared to other rice cultivars under nonsaline and saline conditions (Table 1, Fig. 2 and 3).

Data for net $\mathrm{CO}_{2}$ assimilation rate $(A)$, transpiration rate $(E)$ and stomatal conductance $\left(g_{s}\right)$ revealed that salinization significantly $(P \leq 0.001)$ reduced $A, E$, water use efficiency $(A / E)$ and $g_{s}$ of all four rice cultivars. However, foliar application of neomycine showed significant $(P \leq 0.001)$ effect to ameliorate adverse effects of salt stress by increasing the level of $A$ and $E$ in all rice cultivars. All rice cultivars showed uniform behavior for above mentioned variables (Table1 and 2; Fig. 3 and 4).

Exogenously applied neomycine and imposition of salt stress caused non-significant effect on sub-stomatal $\mathrm{CO}_{2}$ concentrations $\left(C_{i}\right)$ and $C_{i} / C_{a}$ ratio also. Response of all four rice cultivars was also uniform with respect to these attributes (Table 2, Fig. 4).

Salinity stress slightly $(P \leq 0.05)$ increased efficiency of photosystem-II $(F v / F m)$ while did not alter electron transport ratio $(E T R)$ in all four rice cultivars. Foliar application of neomycine showed considerable $(P \leq 0.01)$ decrease in $F v / F m$ and increase in ETR of all rice cultivars under saline stress (Table 2; Fig. 4 and 5).

Salt stress showed significant $(P \leq 0.001)$ decrease in non-photochemical quenching $(N P Q)$, co-efficient of non-photochemical quenching $\left(\mathrm{q}_{\mathrm{N}}\right)$ and photochemical quenching $\left(\mathrm{q}_{\mathrm{P}}\right)(P \leq 0.05)$ in all rice cultivars. However,
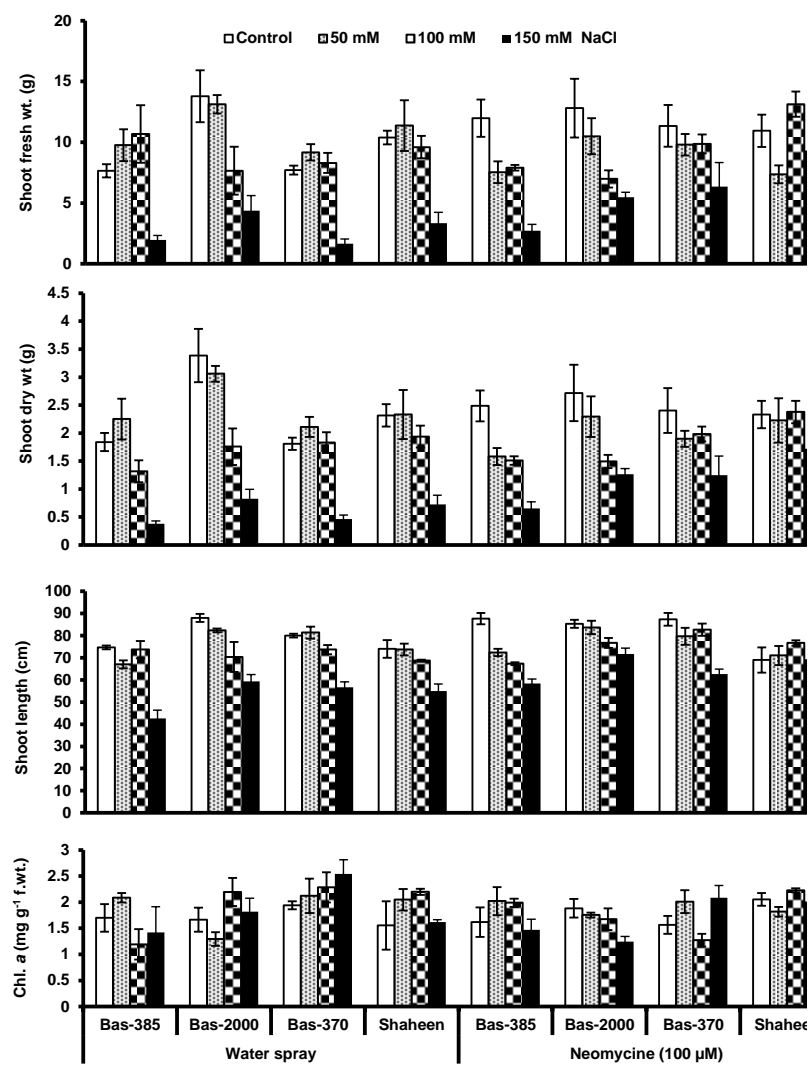

Fig. 1: Growth attributes and chlorophyll (Chl.) $a$ contents of rice plants exposed to neomycine under control or saline conditions (Mean \pm S.E., $n=4$ )

foliar application of neomycine showed non-significant effect on these attributes in all rice cultivars. Among four rice cultivars a considerable variation was observed as the cultivar cv. Bas-2000 performed better as compared to others under control and saline conditions (Table 2, Fig. 5).

Imposition of salt stress and foliar application of neomycine enhanced leaf free proline in all four rice cultivars. All four cultivars showed significant variation, particularly Bas-370 accumulated more free proline contents under salt stress (Table 2, Fig. 6).

Varying levels of salt stress considerably $(P \leq 0.001)$ increased shoot and root $\mathrm{Na}^{+}, \mathrm{K}^{+}$and $\mathrm{Ca}^{2+}$ in four rice cultivars (Bas-385, Bas-2000, Bas-370 and Shaheen). However foliar application of neomycine showed nonsignificant effect on shoot and root $\mathrm{Na}^{+}$in all rice cultivars. Exogenous application of neomycine was proved to be significant $(P \leq 0.05$ and 0.001$)$ for increase in shoot $\mathrm{K}^{+}$but decrease in root $\mathrm{K}^{+}$in four rice cultivars. In case of $\mathrm{Ca}^{2+}$ accumulation, neomycine only slightly significantly decreased level of shoot $\mathrm{Ca}^{2+}$ in all rice cultivars. Among four cultivars all show significant $(P \leq 0.001)$ variation particularly, cv. Bas-385 showed more ion accumulation in control and cv. Shaheen in neomycine treated rice plants (Table 2; Fig. 6 and 7). 
Table 1: Mean squares from analysis of variance of data for growth attributes, photosynthetic pigments, water relations and gas exchange characteristics of rice when 52-day old plants were subjected to neomycine under control or saline condition

\begin{tabular}{|c|c|c|c|c|c|}
\hline$\overline{\mathrm{SOV}}$ & $\mathrm{df}$ & Shoot f.wt. & Shoot d.wt. & Shoot length & Chl $a$ \\
\hline Salinity & 3 & $262.02 * * *$ & $14.28 * * *$ & $2715.7 * * *$ & $0.171 \mathrm{~ns}$ \\
\hline Neomycine (Neo) & 1 & $22.65 \mathrm{~ns}$ & $0.426 \mathrm{~ns}$ & $806.6^{* * *}$ & $0.122 \mathrm{~ns}$ \\
\hline Cultivars (Cv) & 3 & $29.07 * *$ & $2.347 * * *$ & $633.7 * * *$ & $0.788^{*}$ \\
\hline $\mathrm{S} \times \mathrm{Neo}$ & 3 & $39.90 * *$ & $1.506^{* * * *}$ & $196.2 * *$ & $0.114 \mathrm{~ns}$ \\
\hline $\mathrm{S} \times \mathrm{CV}$ & 9 & $17.97 *$ & $0.562 *$ & $150.4 * * *$ & $0.512 *$ \\
\hline $\mathrm{Cv} \times \mathrm{Neo}$ & 3 & $18.73 \mathrm{~ns}$ & $0.749 \mathrm{~ns}$ & $15.79 \mathrm{~ns}$ & $0.789 *$ \\
\hline $\mathrm{Cv} \times \mathrm{S} \times \mathrm{Neo}$ & 9 & $9.972 \mathrm{~ns}$ & $0.202 \mathrm{~ns}$ & $97.28 * *$ & $0.430 *$ \\
\hline Error & 96 & 7.037 & 0.278 & 36.21 & 0.211 \\
\hline Salinity & 3 & $0.052 \mathrm{~ns}$ & $0.090 \mathrm{~ns}$ & $1.562 * * *$ & $3.078^{* * *}$ \\
\hline Neomycine (Neo) & 1 & $0.228^{*}$ & $0.254 \mathrm{~ns}$ & $0.459 * * *$ & $0.003 \mathrm{~ns}$ \\
\hline Cultivars $(\mathrm{Cv})$ & 3 & $0.321 * *$ & $0.792 \mathrm{~ns}$ & $0.163 * * *$ & $0.035^{* * *} *$ \\
\hline $\mathrm{S} \times \mathrm{Neo}$ & 3 & $0.069 \mathrm{~ns}$ & $0.132 \mathrm{~ns}$ & $0.025 \mathrm{~ns}$ & $0.233^{* * * *}$ \\
\hline $\mathrm{S} \times \mathrm{Cv}$ & 9 & $0.167 * *$ & $0.510 \mathrm{~ns}$ & $0.063 * *$ & $0.030 * * *$ \\
\hline $\mathrm{Cv} \times \mathrm{NeO}$ & 3 & $0.417 * * *$ & $1.137 \mathrm{~ns}$ & $0.021 \mathrm{~ns}$ & $0.099 * * *$ \\
\hline $\mathrm{Cv} \times \mathrm{S} \times \mathrm{Neo}$ & 9 & $0.111 \mathrm{~ns}$ & $0.451 \mathrm{~ns}$ & $0.065^{* *}$ & $0.044 * * *$ \\
\hline Error & 96 & 0.057 & 0.663 & 0.021 & 0.001 \\
\hline Salinity & 3 & $0.344 * * *$ & $17.47 * * *$ & $1.342 * * *$ & $778.4 * * *$ \\
\hline Neomycine (Neo) & 1 & $0.542^{* * * *}$ & $0.793^{* * *} *$ & $2.524 * * *$ & $534.4^{*}$ \\
\hline Cultivars $(\mathrm{Cv})$ & 3 & $0.158^{* * *}$ & $0.284 \mathrm{~ns}$ & $0.037 \mathrm{~ns}$ & $899.5^{* * * *}$ \\
\hline $\mathrm{S} \times \mathrm{Neo}$ & 3 & $0.109^{* *}$ & $0.290 \mathrm{~ns}$ & $0.383 * * *$ & $266.3^{*}$ \\
\hline $\mathrm{S} \times \mathrm{Cv}$ & 9 & $0.085^{* * *} *$ & $1.628 * * *$ & $0.123 * * *$ & $257.5^{* *}$ \\
\hline $\mathrm{Cv} \times \mathrm{NeO}$ & 3 & $0.093^{* *} *$ & $0.747 \mathrm{~ns}$ & $0.012 \mathrm{~ns}$ & $31.60 \mathrm{~ns}$ \\
\hline $\mathrm{Cv} \times \mathrm{S} \times \mathrm{Neo}$ & 9 & $0.123^{* * *} *$ & $0.365 \mathrm{~ns}$ & $0.049 * *$ & $197.2 *$ \\
\hline Error & 96 & 0.020 & 0.375 & 0.017 & 80.51 \\
\hline
\end{tabular}

ns $=$ non-significant, $*$, ** and *** significant at $0.05,0.01$ and 0.001 levels, respectively

Table 2: Mean squares from analysis of variance of data for gas exchange characteristics, chlorophyll fluorescence attributes mineral ions and proline of rice plants exposed to neomycine under control or saline condition

\begin{tabular}{|c|c|c|c|c|c|}
\hline SOV & $\overline{\mathrm{df}}$ & $g_{s}$ & $C_{i}$ & $C_{i} / C_{a}$ & $F v / F m$ \\
\hline Salinity & 3 & $50971.7 * * *$ & $684.9 \mathrm{~ns}$ & $0.005 \mathrm{~ns}$ & $0.021^{*}$ \\
\hline Neomycine (Neo) & 1 & $23112.5 * * *$ & $2444.2 \mathrm{~ns}$ & $0.019 \mathrm{~ns}$ & $0.048 * *$ \\
\hline Cultivars (Cv) & 3 & $2368.05 \mathrm{~ns}$ & $1017.5 \mathrm{~ns}$ & $0.008 \mathrm{~ns}$ & $0.009 \mathrm{~ns}$ \\
\hline $\mathrm{S} \times \mathrm{Neo}$ & 3 & 3201.39ns & $7049.4 * *$ & $0.057 * *$ & $0.093^{* * * *}$ \\
\hline $\mathrm{S} \times \mathrm{Cv}$ & 9 & $1847.1 \mathrm{~ns}$ & $9943.1 * * *$ & $0.080 * * *$ & $0.015^{*}$ \\
\hline $\mathrm{Cv} \times \mathrm{Neo}$ & 3 & $4953.2 * *$ & $7687.4 * *$ & $0.062 * *$ & $0.009 \mathrm{~ns}$ \\
\hline $\mathrm{Cv} \times \mathrm{S} \times \mathrm{Neo}$ & 9 & $6355.7 * * *$ & $5127.5^{* * *}$ & $0.041^{* * *} *$ & $0.017 * *$ \\
\hline Error & 96 & 1205.5 & 1355.6 & 0.011 & 0.006 \\
\hline Salinity & 3 & $11.53 \mathrm{~ns}$ & $0.077 * * *$ & $0.023 * * *$ & $0.030 *$ \\
\hline Neomycine (Neo) & 1 & $35.64 * *$ & $0.026 \mathrm{~ns}$ & $0.010 \mathrm{~ns}$ & $0.0007 \mathrm{~ns}$ \\
\hline Cultivars $(\mathrm{Cv})$ & 3 & $11.66 \mathrm{~ns}$ & $0.071 * * *$ & $0.019 * * *$ & $0.114 \mathrm{~ns}$ \\
\hline $\mathrm{S} \times \mathrm{NeO}$ & 3 & $16.70 *$ & $0.006 \mathrm{~ns}$ & $0.007 \mathrm{~ns}$ & $0.030^{*}$ \\
\hline $\mathrm{S} \times \mathrm{Cv}$ & 9 & $6.847 \mathrm{~ns}$ & $0.041 * * *$ & $0.011^{* * *} *$ & $0.011 \mathrm{~ns}$ \\
\hline $\mathrm{Cv} \times \mathrm{Neo}$ & 3 & $9.241 \mathrm{~ns}$ & $0.002 \mathrm{~ns}$ & $0.001 \mathrm{~ns}$ & $0.020 \mathrm{~ns}$ \\
\hline $\mathrm{Cv} \times \mathrm{S} \times \mathrm{Neo}$ & 9 & $7.825 \mathrm{~ns}$ & $0.029^{* *}$ & $0.009^{* *}$ & $0.015 \mathrm{~ns}$ \\
\hline Error & 96 & 4.361 & 0.009 & 0.003 & 0.010 \\
\hline Salinity & 3 & $255.4 * * *$ & $297.7 * * *$ & $47.23 * * *$ & $4.516^{* *}$ \\
\hline Neomycine (Neo) & 1 & $0.002 \mathrm{~ns}$ & $2.438 \mathrm{~ns}$ & $3.337 *$ & $16.65^{* * * *}$ \\
\hline Cultivars $(\mathrm{Cv})$ & 3 & $19.51 * * *$ & $8.258 * * *$ & $6.291 * * *$ & $6.407 * *$ \\
\hline $\mathrm{S} \times \mathrm{NeO}$ & 3 & $50.45 * * *$ & $12.16^{* * * *}$ & $35.29 * * *$ & $2.727 \mathrm{~ns}$ \\
\hline $\mathrm{S} \times \mathrm{Cv}$ & 9 & $6.092 *$ & $10.47^{*}$ & $21.89 \mathrm{~ns}$ & $1.327 \mathrm{~ns}$ \\
\hline $\mathrm{Cv} \times \mathrm{Neo}$ & 3 & $23.77 *$ & $13.02 \mathrm{~ns}$ & $10.01 \mathrm{~ns}$ & $2.593 \mathrm{~ns}$ \\
\hline $\mathrm{Cv} \times \mathrm{S} \times \mathrm{Neo}$ & 9 & $26.68 \mathrm{~ns}$ & $8.169^{* * *}$ & $4.522 *$ & $3.202 * *$ \\
\hline Error & 96 & 0.921 & 0.974 & 0.712 & 1.107 \\
\hline SOV & $\mathrm{df}$ & Shoot $\mathrm{Ca}^{2+}$ & Root $\mathrm{Ca}^{2+}$ & Leaf free proline & \\
\hline Salinity & 3 & $23.66 * * *$ & $0.832 \mathrm{~ns}$ & $1.088^{* * *}$ & \\
\hline Neomycine (Neo) & 1 & $2.042 *$ & $0.681 \mathrm{~ns}$ & $0.971^{* * *} *$ & \\
\hline Cultivars (Cv) & 3 & $6.157 * * *$ & $0.092 \mathrm{~ns}$ & $0.098^{* *} *$ & \\
\hline $\mathrm{S} \times \mathrm{NeO}$ & 3 & $5.291 * * *$ & $0.063 \mathrm{~ns}$ & $0.207 * * *$ & \\
\hline $\mathrm{S} \times \mathrm{Cv}$ & 9 & $1.391 * *$ & $0.182 \mathrm{~ns}$ & $0.018 \mathrm{~ns}$ & \\
\hline $\mathrm{Cv} \times \mathrm{Neo}$ & 3 & $20.92 * * *$ & $0.106 \mathrm{~ns}$ & $0.018 \mathrm{~ns}$ & \\
\hline $\mathrm{Cv} \times \mathrm{S} \times \mathrm{Neo}$ & 9 & $2.694 * * *$ & $0.379 \mathrm{~ns}$ & $0.016 \mathrm{~ns}$ & \\
\hline Error & 96 & 0.475 & 0.461 & 0.022 & \\
\hline
\end{tabular}

ns $=$ non-significant, $* * *$ and $* * *$ significant at $0.05,0.01$ and 0.001 levels, respectively 

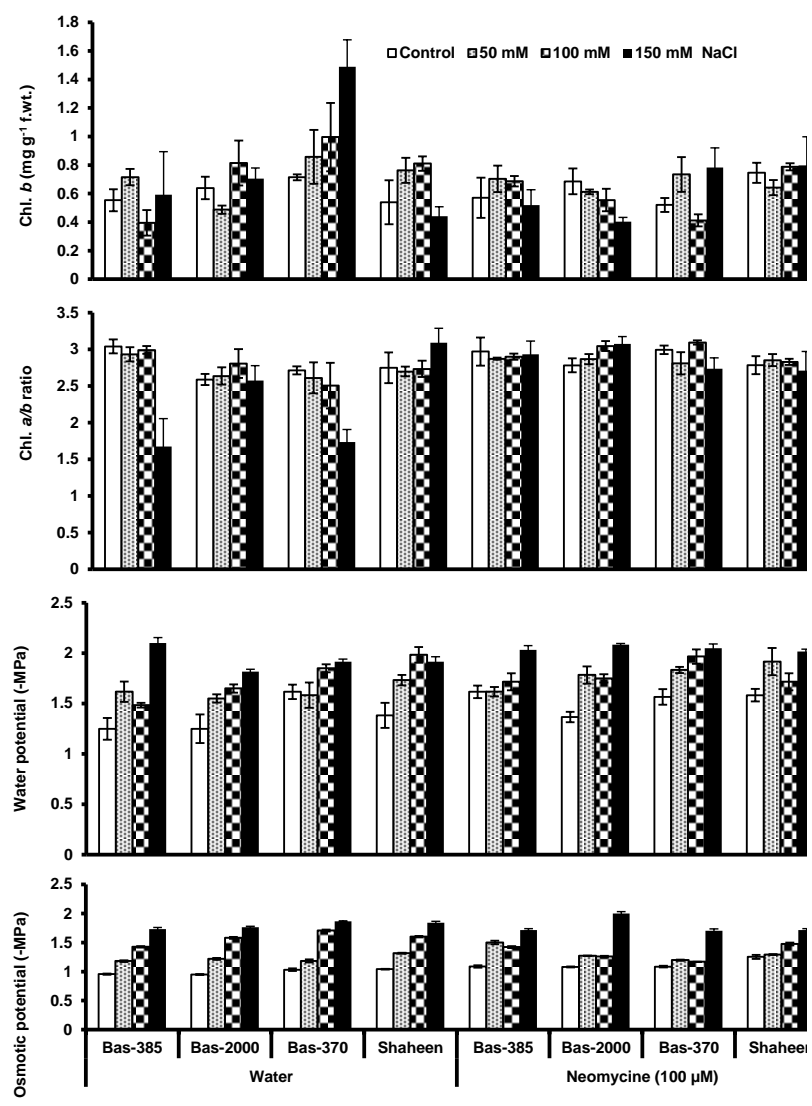

Fig. 2: Chlorophyll (Chl.) and water relation attributes of rice plants exposed to neomycine under control or saline conditions (Mean \pm S.E., $n=4$ )

\section{Discussion}

Saline stress adversely affects plant growth and production by modulation in physio-biochemical processes (Perveen $e t$ al., 2013) like photosynthetic system as well as gas exchange characteristics severely affected by salt stress (Ashraf et al., 2010). In present study, salt stress $(0,50$, 100 and $150 \mathrm{mM}$ ) reduced the growth of all four rice cultivars. Salinity had an inhibitory effect on all growth attributes of various plants like rice (Shahbaz and Zia, 2011) and wheat (Shahbaz et al., 2008; Kanwal et al., 2011; Ashraf et al., 2012). The reduced water uptake capacity due to salinity resulted in decreased $\Psi_{\mathrm{w}}$ and affects growth of plants (Sabir and Ashraf, 2007). Exogenous application of neomycine as PLC inhibitor showed non-significant effect on shoot fresh and dry weights while shoot length of all rice cultivars (Bas-385, Bas-2000, Bas-370 and Shaheen) was slightly increased. It has been reported that salt stress inhibits plant growth and development by activating kinase-dependent pathways and increased with increasing concentration of salt stress concentration however, neomycin a phospholipase C inhibitor inhibits this activity by increasing growth characteristics in soybean (Im et al., 2012).
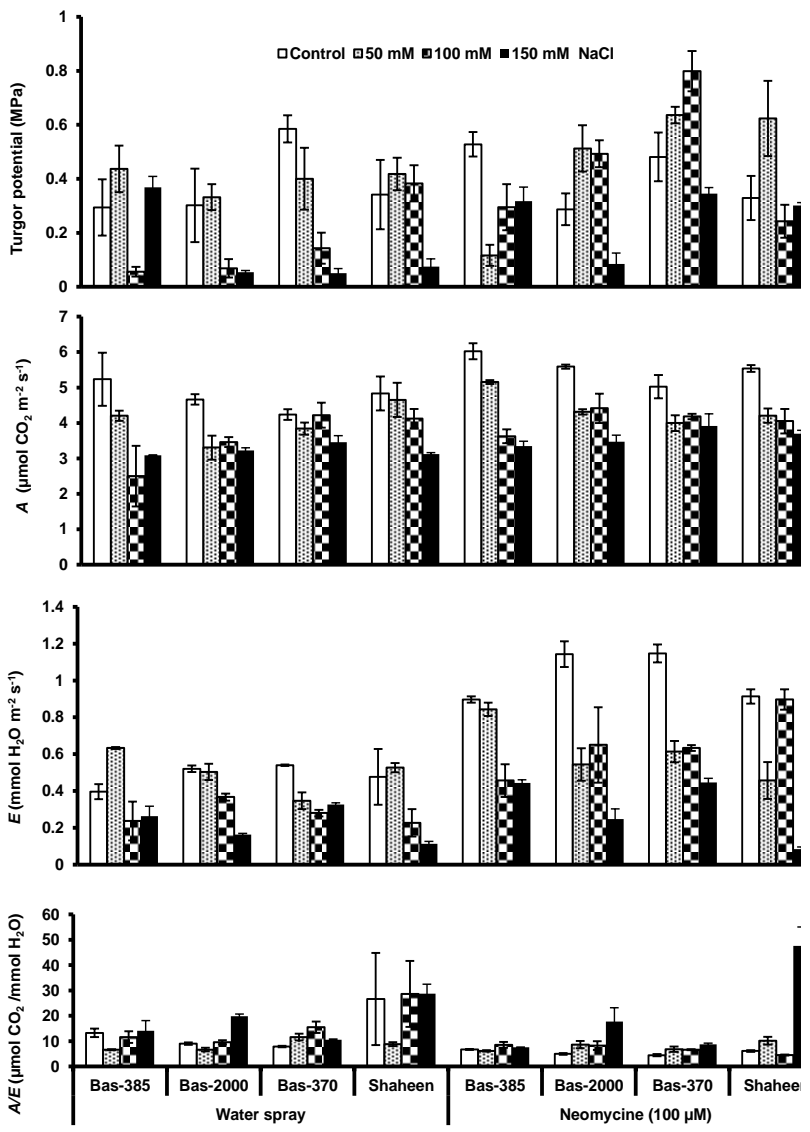

Fig. 3: Leaf turgor potential and gas exchange characteristics of rice plants exposed to neomycine under control or saline conditions (Mean \pm S.E., $n=4$ )

Salt stress caused photo-oxidation in plants (Lawlor and Tezara, 2009) that is highly sensitive for photosynthetic pigments (Carpentier, 1997). In present study, salt stress showed non-significant effects on chlorophyll contents. Perveen et al. (2010) reported that in wheat salt stress showed non-significant effect on chlorophyll contents. Exogenous application of neomycine did not alter chlorophyll $a$ and $a / b$ ratio, which shows that PLC has no influence on this attribute, while it slightly increased chlorophyll $b$. In contrast to our findings, it has been reported that PLC increased the accumulation of chlorophyll contents by increasing $\mathrm{Ca}^{2+}$ level in cytosol (Brini et al., 2007; Mahajan et al., 2008; Munns and Tester, 2008).

Salinity reduced plant water uptake capacity from the soil (Munns, 2005). In this experiment, salinity significantly increased leaf $\Psi_{\mathrm{w}}$ and $\Psi_{\mathrm{s}}(-\mathrm{MPa})$ as well as $\Psi_{\mathrm{p}}$ in all rice cultivars. Decrease in $\Psi_{\mathrm{s}}$ is due to increased accumulation of organic as well as inorganic solutes to maintain water homeostasis and decreasing $\Psi_{\mathrm{w}}$ (Ashraf, 2004). Same results were observed in some previous findings on various crops like proso millet (Sabir and Ashraf, 2008), barley (Vysotskaya et al., 2010) and wheat (Ali et al., 2008) in which decreased $\Psi_{\mathrm{w}}$ as well as $\Psi_{\mathrm{s}}$ caused decrease in plant 

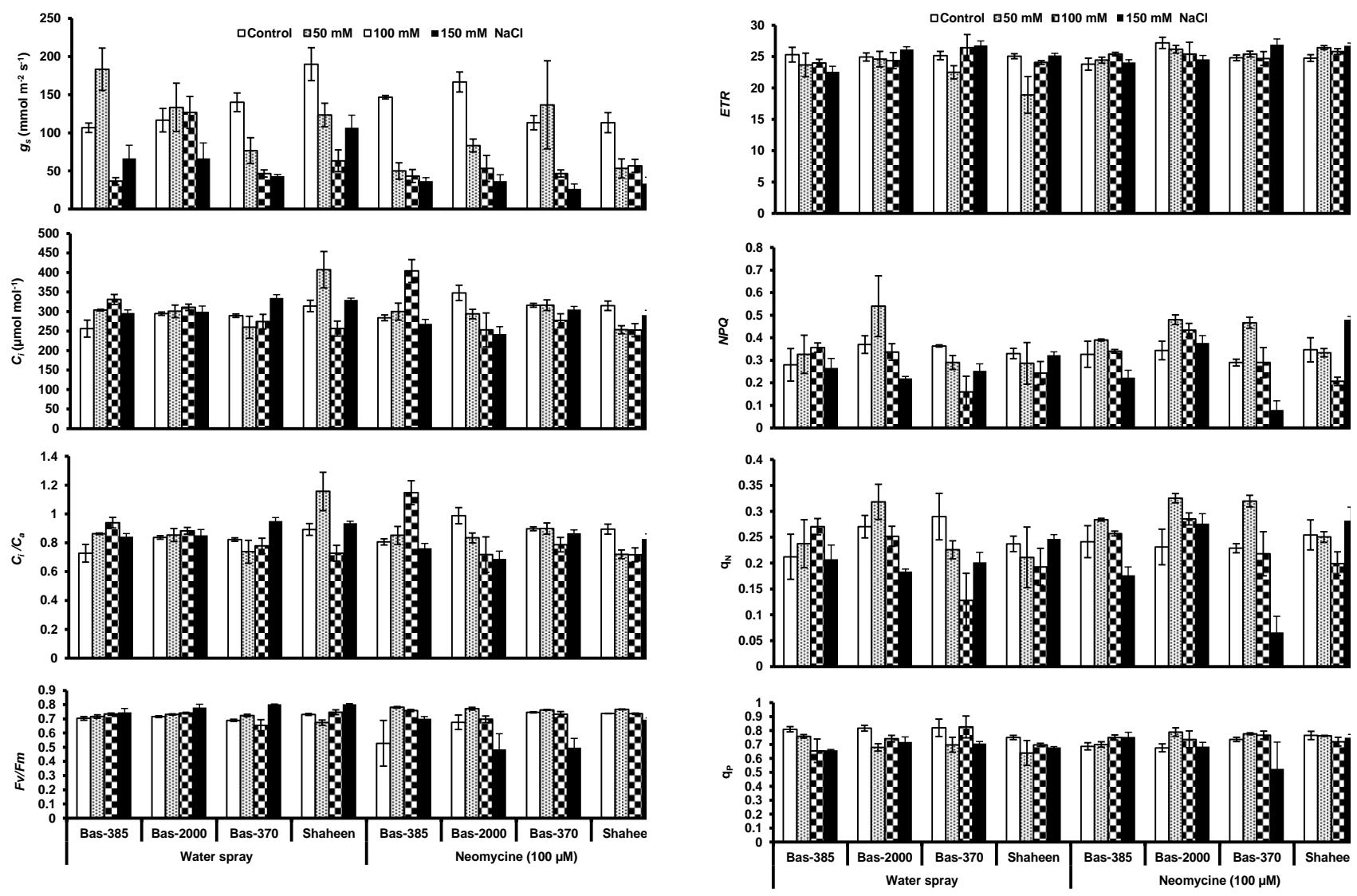

Fig. 4: Gas exchange characteristics and chlorophyll fluorescence of rice plants exposed to neomycine under control or saline conditions (Mean \pm S.E., $n=4$ )

growth. Exogenous application of neomycine has nonsignificant effect on leaf $\Psi_{\mathrm{s}}$ while significantly increased $\Psi_{\mathrm{w}}$ and $\Psi_{\mathrm{p}}$. This significant increase in water potential due to neomycine shows that PLC has some role in water relations of rice (Hunt et al., 2003). It has been reported that PLC clearly play a role in the early signal transduction events associated with water potential and osmoregulation in plants by increasing the level of $\mathrm{IP}_{3}$ and rise in cytosolic calcium as observed in Arabidopsis (Alexandre et al., 1990; Knight et al., 1997; Drobak and Watkins, 2000).

In the present study, salinization considerably reduced gas exchange attributes: photosynthetic rate $(A)$, transpiration rate $(E)$ and stomatal conductance $\left(g_{s}\right)$ which is analogous to the findings of different reports e.g., in Brassica spp. (Nazir et al., 2001) and wheat (James et al., 2002). Growth of plants is directly related to the photosynthesis for example Hichem et al. (2009) suggested that in maize plants photosynthetic rate is associated with growth under saline conditions. Exogenous application of PLC inhibitors targets the role of PLC in photosynthetic system of rice to analyze the salt tolerance. Foliar applied neomycine had significant increasing effect on $A$ and $E$ while decreased $g_{s}$ and $A / E$ level indicating the role of PLC in signaling mechanism due to salt stress.

Fig. 5: Chlorophyll fluorescence of rice plants exposed to neomycine under control or saline conditions (Mean \pm S.E., $n=4)$

Quantum yield of PSII in terms of ETR remained unchanged under salt stress while significant effect on $F v / F m, N P Q, \mathrm{q}_{\mathrm{N}}$ and $\mathrm{q}_{\mathrm{P}}$ was observed in all rice cultivars as reported wheat (Shahbaz and Ashraf, 2007). To observe the role of PLC in chlorophyll fluorescence attributes the effect of PLC inhibitor neomycine was applied and a slight significant decreasing effect for $F v / F m$ and ETR was observed. The non-significant effect of neomycine on all other chlorophyll fluorescence attributes revealed that there is no role of PLC in regulating the mechanism of these PSII attributes.

Of various inorganic solutes such as potassium and calcium participate in osmotic adjustment while $\mathrm{Na}^{+}$caused ion toxicity in plants (Wenxue et al., 2003). The current findings showed the significant increase in accumulation of $\mathrm{Na}^{+}$in all rice cultivars due to salt stress. Similar findings were obtained in different crops e.g., maize (Zhang et al., 2006) and wheat (James et al., 2011). Salinity increased $\mathrm{Na}^{+}$accumulation also affects the plant water relation attributes thus decreasing growth as observed in previous studies e.g., in rice (Cha-um et al., 2010) and pearl millet (Hussain et al., 2008). There is non-significant effect of neomycine on $\mathrm{Na}^{+}$accumulation in shoot and root 

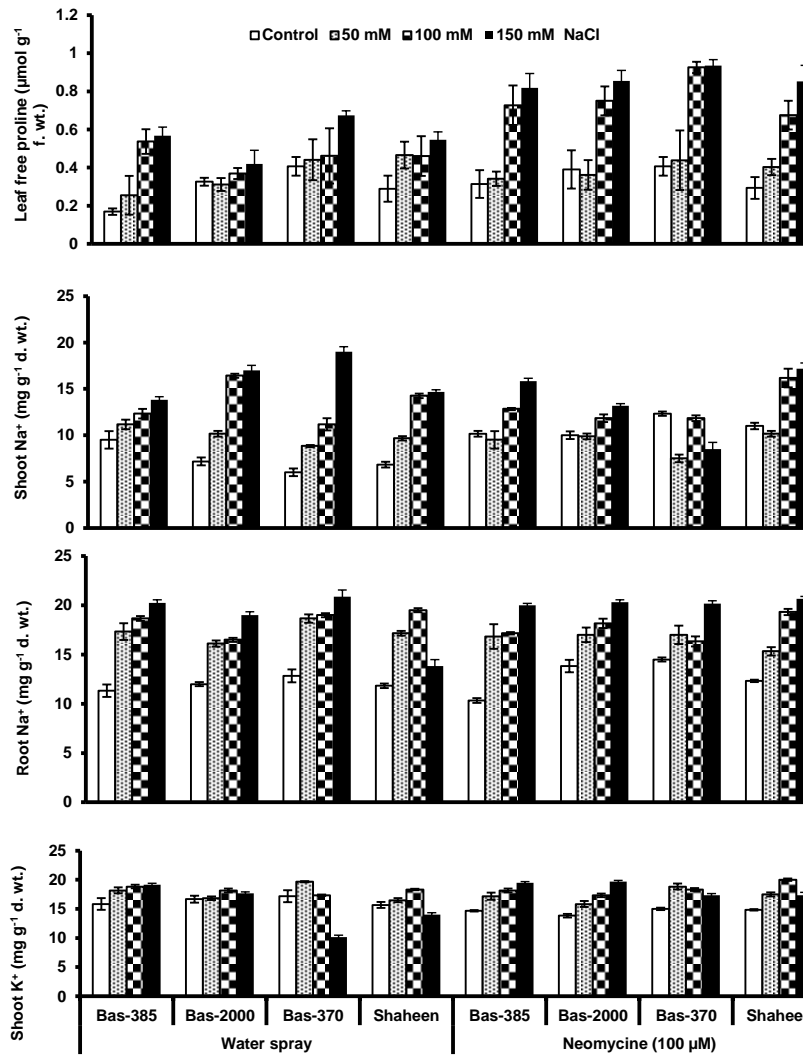

Fig. 6: Leaf free proline contents and mineral ions in rice plants exposed to neomycine under control or saline conditions (Mean \pm S.E., $n=4$ )

of all rice cultivars that confirmed no role of PLC in $\mathrm{Na}^{+}$ accumulation rice.

In this experiment, $\mathrm{K}^{+}$and $\mathrm{Ca}^{2+}$ accumulation was decreased due to salinity as observed in mungbean plants (Haleem and Mohammed, 2007; Huo et al., 2015) and barley (Othman et al., 2006). Reduction in $\mathrm{K}^{+}$level resulted in reduced growth by decreasing osmotic adjustment and turgor maintenance as observed in maize (Karmoker et al., 2008) as well as in rice plants (Sakamoto and Murata, 2001). Results of this experiment indicated that PLC is involved in $\mathrm{K}^{+}$and $\mathrm{Ca}^{2+}$ accumulation as observed with the significant effect of exogenous application of neomycine. This effect was not consistent in shoot and root potassium and calcium accumulation. It has been reported that potassium and calcium is an essential nutrient for growth and development of plants. They play important role in plant tissues resistance under salt stress conditions (Kaur and Gupta, 2005). This level of cytosolic calcium was increased due to PLC by increasing level of $\mathrm{IP}_{3}$ (Legendre $e t$ al., 1993; Staxen et al., 1999). Neomycine blocks the activity of PLC thereby decreasing the concentration of calcium (Quarmby et al., 1992; Takahashi et al., 2001).

Proline helps in osmotic adjustment and causes stress tolerance in plants (Hasegawa et al., 2000). In this
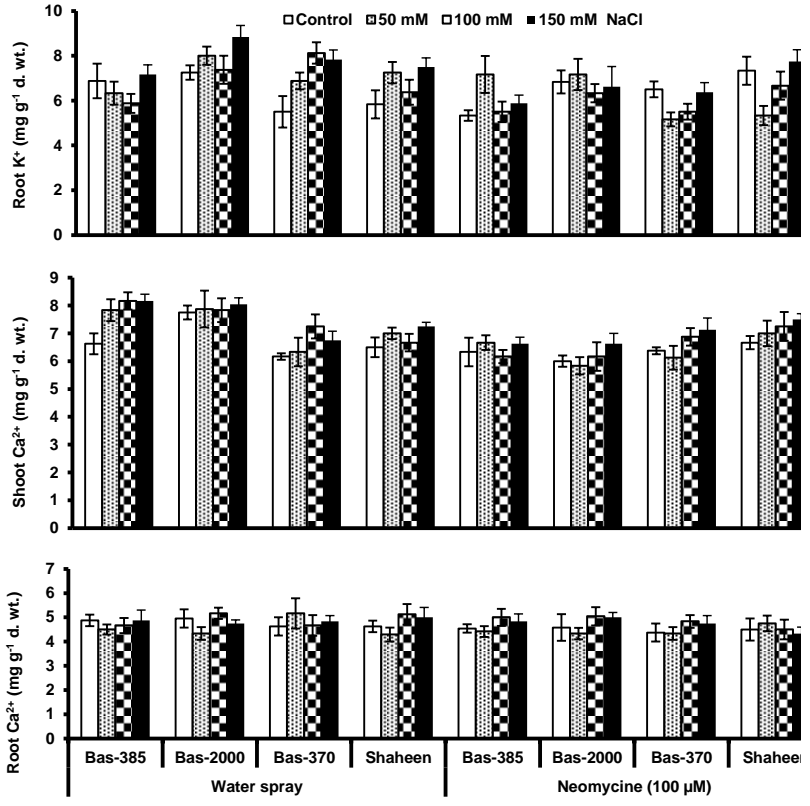

Fig. 7: Mineral nutrients in rice plants exposed to neomycine under control or saline conditions (Mean \pm S.E., $n=4)$

experiment, salinity increased level of free proline in all rice cultivars. Higher accumulation of free proline helps in osmotic adjustment by reducing $\mathrm{Na}^{+}$toxicity in saline conditions (Akca and Samsunlu, 2012). These results demonstrate similar activities with some previous studies e.g. salt stress resulted in increased contents of free proline in barley (Khosravinejad et al., 2009) and soybean (Krezhova et al., 2009). In this experiment it has been reported that foliar applied neomycine showed significant increase in proline accumulation in all rice cultivars. These results confirm the role of PLC in accumulation of free proline for salt stress tolerance. In response to salt stress conditions, plants accumulate high contents of proline by regulating proline metabolism due to PLC. In proline accumulation role of PLC was appraised by using PLC inhibitor, which reduces pyrroline-5-carboxylate synthetase transcript and protein as well as proline levels in salt stressed plants. Inhibition of PLC activity by neomycine has been measured by decreased level of $\mathrm{IP}_{3}$ in Arabidopsis (Parre et al., 2007).

\section{Conclusion}

In conclusion, salt stress applied through root growing medium decreased various morpho-physiological attributes of all four rice cultivars. However, foliar-applied neomycine slightly increased shoot length, gas exchange characteristics, efficiency of photosystem II and leaf free proline contents and decreased accumulation of $\mathrm{Ca}^{2+}$. Of all rice cultivars, cv. Bas-2000 performed better in growth, water relation and 
photosynthetic attributes under saline and non-saline conditions.

\section{Acknowledgments}

The data presented in manuscript are part of Ph.D. thesis of Miss Atifa Masood and authors gratefully acknowledge the Higher Education Commission, Pakistan for providing funds for current study through Indigenous Scholarship Ph.D. Fellowship Program (Phase-II) (Pin No. 112-256652Bm1-199) and NRPU grant no. 20-1735.

\section{References}

Ahmad, M., Z.A. Zahir, M. Khalid, F. Nazli and M. Arshad, 2013. Efficacy of Rhizobium and Pseudomonas strains to improve physiology, ionic balance and quality of mung bean under salt-affected conditions on farmer's fields. Plant Physiol. Biochem., 63: 170-176

Akca, Y. and E. Samsunlu, 2012. The effect of salt stress on growth, chlorophyll content, proline and nutrient accumulation, and $\mathrm{K} / \mathrm{Na}$ ratio in walnut. Pak. J. Bot., 44: 1513-1520

Alexandre, J., J.P. Lassalles and R.T. Kado, 1990. Opening of $\mathrm{Ca}^{2+}$ channels in isolated red beet root vacuole membrane by inositol 1,4,5trisphosphate. Nature, 343: 567-570

Ali, Q., H.R. Athar and M. Ashraf, 2008. Modulation of growth, photosynthetic capacity and water relations in salt stressed wheat plants by exogenously applied 24-epibrassinolide. Plant Growth Regul., 56: 107-116

Allen, S.E., H.M. Grimshaw and A.P. Rowland, 1986. Chemical analysis. In: Methods in Plant Ecology, $2^{\text {nd }}$ edition, pp: 258-344. Moore, P.D. and S.B. Chapman (eds.). Blackwell Publications, Oxford, UK

Arnon, D.T., 1949. Copper enzyme in isolated chloroplasts polyphenol oxidase in Beta vulgaris. Plant Physiol., 24: 1-15

Ashraf, M., 2004. Some important physiological selection criteria for salt tolerance in plants. Flora, 199: 361-376

Ashraf, M., N.A. Akram, R.N. Arteca and M.R. Foolad, 2010. The physiological, biochemical and molecular roles of brassinosteroids and salicylic acid in plant processes and salt tolerance. Crit. Rev. Plant Sci., 29: 162-190

Ashraf, M.A., M. Ashraf and M. Shahbaz, 2012. Growth stage-based modulation in antioxidant defense system and proline accumulation in two hexaploid wheat (Triticum aestivum L.) cultivars differing in salinity tolerance. Flora, 207: 388-397

Bates, L.S., R.P. Waldren and I.D. Teare, 1973. Rapid determination of free proline for water stress studies. Plant Soil, 39: 205-207

Brini, F., M. Hanin, I. Mezghani, G.A. Berkowitz and K. Masmoudi, 2007. Overexpression of wheat $\mathrm{Na}^{+} / \mathrm{H}^{+}$antiporter TNHX1 and $\mathrm{H}^{+}-$ pyrophosphatase TVP1 improve salt- and drought-stress tolerance in Arabidopsis thaliana plants. J. Exp. Bot., 58: 301-308

Carpentier, R., 1997. Influence of High Light Intensity on Photosynthesis: Photo-inhibition and Energy Dissipation. Taylor and Francis Group, LLC, New York, USA

Cha-um, S., K. Siringamb, N. Juntawongb and C. Kirdmaneea, 2010. Water relations, pigment stabilization, photosynthetic abilities and growth improvement in salt stressed rice plants treated with exogenous potassium nitrate application. Int. J. Plant Prod., 4: 187-198

Coursol, S., N. Giglioli-Guivarc'h, J. Vidal and J.N. Pierre, 2000. An increase in phosphoinositide-specific phospholipase $\mathrm{C}$ activity precedes induction of $\mathrm{C}_{4}$ phosphoenolpyruvate carboxylase phosphorylation in illuminated and $\mathrm{NH}_{4} \mathrm{Cl}$-treated protoplasts from Digitaria sanguinalis. Plant J., 23: 497-506

Drobak, B.K. and P.A. Watkins, 2000. Inositol (1, 4, 5) trisphosphate production in plant cells: An early response to salinity and hyperosmotic stress. FEBS Lett., 481: 240-244

Gopikannan, M. and S.K. Ganesh, 2013. Inter-relationship and path analysis in rice (Oryza sativa L.) under sodicity. Ind. J. Sci. Technol., 6: 5223-5227
Haleem, A. and M.A. Mohammed, 2007. Physiological aspects of mungbean plant (Vigna radiata L. Wilczek) in response to salt stress and gibberellic acid treatment. Res. J. Agric. Biol. Sci., 3: 200-213

Hasegawa, P.M., R.A. Bressan, J.K. Zhu and H.J. Bohnert, 2000. Plant cellular and molecular responses to high salinity. Annu. Rev. Plant Physiol. Plant Mol. Biol., 51: 463-499

Hichem, H., E.A. Naceur and D. Mounir, 2009. Effects of salt stress on photosynthesis, PSII photochemistry and thermal energy dissipation in leaves of two corn (Zea mays L.) varieties. Photosynthetica, 47: $517-526$

Holdaway-Clarke, T.L. and P.K. Hepler, 2003. Control of pollen tube growth: role of ion gradients and fluxes. New Phytol., 159: 539-563

Hossain, M.A., M. Ashrafuzzaman and M.R. Ismail, 2011. Salinity triggers proline synthesis in peanut leaves. Maejo Int. J. Sci. Technol., 5: $159-168$

Huo, P.H., J.F. Li, J.X. Liu, S.Q. Zhang and S.L. Shi, 2015. Cross adaptation of Medicago sativa seedlings germinated from ultra-dried seeds to saline and alkaline stresses. Int. J. Agric. Biol., 17: 860-868

Hunt, L., L.N. Mills, C. Pical, C.P. Leckie, F.L. Aitken, J. Kopka, B. Mueller-Roeber, M.R. McAinsh, A.M. Hetherington and J.E. Gray, 2003. Phospholipase $\mathrm{C}$ is required for the control of stomatal aperture by ABA. Plant J., 34: 47-55

Hussain, K., M. Ashraf and M.Y. Ashraf, 2008. Relationship between growth and ion relation in pearl millet (Pennisetum glaucum (L.) R. Br.) at different growth stages under salt stress. Afr. J. Plant Sci., 2: 23-27

Im, J.H., H. Lee, J. Kim, H.B. Kim, K. Seyoung, B.M. Kim and C.S. An, 2012. A salt stress-activated mitogen-activated protein kinase in soybean is regulated by phosphatidic acid in early stages of the stress response. J. Plant Biol., 55: 303-309

James, R.A., A.R. Rivelli, R. Munns and S.V. Caemmerer, 2002. Factors affecting $\mathrm{CO}_{2}$ assimilation, leaf injury and growth in salt stressed durum wheat. Funct. Plant Biol., 9: 1393-1403

James, R.A., C. Blake, C.S. Byrt and R. Munns, 2011. Major genes for $\mathrm{Na}^{+}$ exclusion, Nax1 and Nax2 (wheat HKT1;4 and HKT1;5), decrease $\mathrm{Na}^{+}$accumulation in bread wheat leaves under saline and waterlogged conditions. J. Exp. Bot., 62: 2939-2947

Jamil, M., S. Bashir, S. Anwar, S. Bibi, A. Bangash, F. Ullah and E.S. Rha, 2012. Effect of salinity on physiological and biochemical characteristics of different varieties of rice. Pak. J. Bot., 44: 7-13

Joseph, E.A. and K.V. Mohanan, 2013. A study on the effect of salinity stress on the growth and yield of some native rice cultivars of Kerala state of India. Agric. Fores. Fish., 2: 141-150

Jouyban, Z., 2012. The effects of salt stress on plant growth. Tech. J. Eng. Appl. Sci., 2: 7-10

Kanwal, H., M. Ashraf and M. Shahbaz, 2011. Assessment of salt tolerance of some newly developed and candidate wheat (Triticum aestivum L.) cultivars using gas exchange and chlorophyll fluorescence attributes. Pak. J. Bot., 43: 2693-2699

Kapoor, D.R.T., 2011. Salinity induced changes in germination, biomass and physiological characteristics of Oryza sativa L. International Conference on Advances in Biotechnology and Pharmaceutical Sciences (ICABPS)

Karmoker, J.L., S. Farhana and P. Rashid, 2008. Effects of salinity on ion accumulation in maize (Zea mays L. cv. bari-7). Bangl. J. Bot., 37: 203-205

Kaur, N. and A.K. Gupta, 2005. Signal transduction pathways under abiotic stresses in plants. Curr. Sci., 88: 1771-1780

Kausar, F., M. Shahbaz and M. Ashraf, 2013. Protective role of foliarapplied nitric oxide in wheat (Triticum aestivum L.) under saline stress. Turk. J. Bot., 37: 1155-1165

Kchaou, H., A. Larbi, K. Gargouri, M. Chaieb, F. Morales and M. Msallem, 2010. Assessment of tolerance to $\mathrm{NaCl}$ salinity of five olive cultivars, based on growth characteristics and $\mathrm{Na}^{+}$and $\mathrm{Cl}^{-}$exclusion mechanisms. Sci. Hortic., 124: 306-315

Khosravinejad, F., R. Heydari and T. Farboodnia, 2009. Effect of salinity on organic solutes contents in barley. Pak. J. Biol. Sci., 15: 158-162

Knight, H., A.J. Trewavas and M.R. Knight, 1997. Calcium signalling in Arabidopsis thaliana responding to drought and salinity. Plant J., 12: 1067-1078 
Krezhova, D., I. Iliev, O. Yanev and E. Kirova, 2009. Assessment of the effect of salinity on the early growth stage of soybean plants (Glycine $\max$ L.). Rec. Adv. Space Technol., 47: 397-402

Lawlor, D.W. and W. Tezara, 2009. Causes of decreased photosynthetic rate and metabolic capacity in water-deficient leaf cells: a critical evaluation of mechanisms and integration of processes. Ann. Bot., 103: 561-579

Legendre, L., Y.G. Yueh, R. Crain, N. Haddock, P.F. Heinstein and P.S. Low, 1993. Phospholipase C activation during elicitation of the oxidative burst in cultured plant cells. J. Biol. Chem., 268: 2455924563

Li, H.W., B.S. Zang, X.W. Deng and X.P. Wang, 2011. Overexpression of the trehalose-6-phosphate synthase gene OsTPS1 enhances abiotic stress tolerance in rice. Planta, 234: 1007-1018

Liu, C., L. Zhao and G. Yu, 2011. The dominant glutamic acid metabolic flux to produce gamma-amino butyric acid over proline in Nicotiana tabacum leaves under water stress relates to its significant role in antioxidant activity. J. Integr. Plant Biol., 53: 608-618

Mahajan, S., G.K. Pandey and N. Tuteja, 2008. Calcium and salt-stress signaling in plants: Shedding light on SOS pathway. Arch. Biochem. Biophys., 471: 146-158

Meijer, H.J.G. and T. Munnik, 2003. Phospholipid-based signaling in plants. Annu. Rev. Plant Biol., 54: 265-306

Mills, L.N., L. Hunt, C.P. Leckie, F.L. Aitken, M. Wentworth, M.R McAinsh, J.E. Gray and A.M. Hetherington, 2004. The effects of manipulating phospholipase $\mathrm{C}$ on guard cell ABA-signaling. J. Exp. Bot., 55: 199-204

Munns, R. and M. Tester, 2008. Mechanisms of salinity tolerance. Аnпи. Rev. Plant Biol., 59: 651-681

Munns, R., 2005. Genes and salt tolerance: bringing them together. New Phytol., 167: 645-663

Nazir, N., M. Ashraf and E. Rasul, 2001. Genomic relationships in oilseed Brassica with respect to salt tolerance-photosynthetic capacity and ion relations. Pak. J. Bot., 33: 483-501

Nivas, D., D.K. Gaikwad and P.D. Chavan, 2011. Physiological responses of two Morinda species under saline conditions. Amer. J. Plant Physiol., 6: 157-166

Nobel, P.S., 1991. Physiochemical and Environmental Plant Physiology. Academic Press, San Diego, California, USA

Othman, Y., G. Al-Karaki, A.R. Al-Tawaha and A. Al-Horani, 2006. Variation in germination and ion uptake in barley genotypes under salinity conditions. World J. Agric. Sci., 2: 11-15

Parre, E., M.A. Ghars, A.S. Leprince, L. Thiery, D. Lefebvre, M. Bordenave, L. Richard, C. Mazars, C. Abdelly and A. Savoure, 2007. Calcium signaling via Phospholipase $C$ is essential for proline accumulation upon ionic but not non-ionic hyperosmotic stresses in Arabidopsis. Plant Physiol., 144: 503-512

Perveen, S., M. Shahbaz and M. Ashraf, 2010. Regulation in gas exchange and quantum yield of photosystem II (PS II) in salt-stressed and nonstressed wheat plants raised from seed treated with triacontanol. Pak. J. Bot., 42: 3073-3081

Perveen, S., M. Shahbaz and M. Ashraf, 2013. Influence of foliar-applied triacontanol on growth, gas exchange characteristics, photosynthetic pigments and chlorophyll flourescence at different growth stages in wheat (Triticum aestivum L.) under saline conditions. Photosynthetica, 51: 541-551

Quarmby, L.M., Y.G. Yueh, J.L. Cheshire, L.R. Keller, W.J. Snell and R.C. Crain, 1992. Inositol phospholipid metabolism may trigger flagellar excision in Chlamydomonas reinhardtii. J. Cell Biol., 6: 737-744

Rao, S.P., B. Mishra, S.R. Gupta and A. Rathore, 2013. Physiological response to salinity and alkalinity of rice genotypes of varying salt tolerance grown in field lysimeters. J. Stress Physiol. Biochem., 9: 54-65

Sabir, P. and M. Ashraf, 2007. Screening of local accessions of Panicum miliaceum L., for salt tolerance at the seedling stage using biomass production and ion accumulation as selection criteria. Pak. J. Bot., 39: $1655-1661$
Sabir, P. and M. Ashraf, 2008. Inter-cultivar variation for salt tolerance in proso millet (Panicum miliaceum L.) at the germination stage. Pak. J. Bot., 40: 677-682

Sakamoto, A. and N. Murata, 2001. The use of bacterial choline oxidase, a glycinebetaine-synthesizing enzyme, to create stress-resistant transgenic plants. Plant Physiol., 125: 180-188

Saleem, M., M. Ashraf and N.A. Akram, 2011. Salt $(\mathrm{NaCl})$ induced modulation in some key physio-biochemical attributes in okra (Abelmoschus esculentus L.). J. Agron. Crop Sci., 197: 202-213

Shafi, M., J. Bakht, M.J. Khan and M.A. Khan, 2010. Effect of salinity and ion accumulation of wheat genotypes. Pak J. Bot., 42: 4113-4121

Shafi, M., J. Bakht, Raziuddin and G. Zhang, 2011. The genotypic difference in inhibition of photosynthesis and chlorophyll fluorescence by salinity and cadmium stresses in wheat. J. Plant Nutr., 34: 315-323

Shahbaz, M. and B. Zia, 2011. Does exogenous application of glycinebetaine through rooting medium alter rice (Oryza sativa L.) mineral nutrient status under saline conditions? J. Appl. Bot. Food Qual., 84: 54-60

Shahbaz, M. and M. Ashraf, 2007. Influence of exogenous application of brassinosteroids on growth and mineral nutrients of wheat (Triticum aestivum L.) under saline conditions. Pak. J. Bot., 39: 513-522

Shahbaz, M. and M. Ashraf, 2013. Improving salinity tolerance in cereals. Critic. Rev. Plant Sci., 32: 237-249

Shahbaz, M., M. Ashraf and H.R. Athar, 2008. Does exogenous application of 24-epibrassinolide ameliorate salt induced growth inhibition in wheat (Triticum aestivum L.)? Plant Growth Regul., 55: 51-64

Shahbaz, M., M. Iqbal and M. Ashraf, 2011. Response of differently adapted populations of blue panic grass (Panicum antidotale Retz.) to water deficit conditions. J. Appl. Bot. Food Qual., 84: 134-141

Shahbaz, M., N. Noreen and S. Perveen, 2013. Triacontanol modulates photosynthesis and osmoprotectants in canola (Brassica napus L.) under saline stress. J. Plant Interact., 8: 250-259

Snedecor, G.W. and G.W. Cochran, 1980. Statistical Methods, $7^{\text {th }}$ edition. Iowa State University Press, Ames, Iowa, USA

Staxen, I.I., C. Pical, L.T. Montgomery, J.E. Gray, A.M. Hetherington and M.R. McAinsh, 1999. Abscisic acid induces oscillations in guardcell cytosolic free calcium that involve phosphoinositide-specific phospholipase C. Proc. Natl. Acad. Sci., 96: 1779-1784

Strasser, R.J., A. Srivastava and Govindjee, 1995. Polyphasic chlorophyll ' $a$ ' fluorescence transients in plants and cyanobacteria. Photochem. Photobiol., 61: 32-42

Scholander, P.F., H.T. Hammel, E.A. Hemmingsen and E.D. Bradstreet, 1964. Hydrostatic pressure and osmotic potential in leaves of mangroves and some other plants. Proc. Natl. Acad. Sci., 52: 119-125

Takahashi, S., T. Katagiri, T. Hirayama, K. Yamaguchi-Shinozaki and K. Shinozaki, 2001. Hyperosmotic stress induces a rapid and transient increase in inositol 1,4,5-trisphosphate independent of abscisic acid in Arabidopsis cell culture. Plant Cell Physiol., 42: 214-222

Vysotskaya, L., P.E. Hedley, G. Sharipova, D. Veselov, G. Kudoyarova, J. Morris and H.G. Jones, 2010. Effect of salinity on water relations of wild barley plants differing in salt tolerance. AoB Plants, 86: 407421

Wang, X., 2001. Plant phospholipases. Annu. Rev. Plant Physiol. Plant Mol. Biol., 52: 211-231

Wenxue, W., P.E. Bilsborrow, P. Hooley, D.A. Fincham, E. Lombi and B.P. Forster, 2003. Salinity induced differences in growth, ion distribution and partitioning in barley in between the cultivars Maythrope and its derived mutant Golden Promise. Plant Soil, 250: 183-191

Zhang, Y., L. Wang, Y. Liu, Q. Zhang, Q. Wei and W. Zhang, 2006. Nitric oxide enhances salt tolerance in maize seedlings through increasing activities of proton-pump and $\mathrm{Na}^{+} / \mathrm{H}^{+}$antiport in the tonoplast. Planta, 224: 545-555

(Received 12 May 2015; Accepted 01 February 2016) 